\title{
Agnieszka Zdanowicz
}

\section{PKYWAJĄCE AUTOBUSY}

DOI: 10.24136/atest.2018.314

Data zgłoszenia: 30.08.2018. Data akceptacji: 25.09.2018.

$W$ artykule przedstawiono innowacyjne koncepcje konstrukcji autobusów amfibia jako środka transportu, zarówno na lądzie, jak i na wodzie.

Amfibia to pojazd o podwójnym zastosowaniu. Możne postużyć do różnych zastosowań $w$ dziedzinie militarnej, operacjach ratowniczych, jak i turystyce.

Artykut koncentruje się na opisie koncepcji „plywajacych autobusów” w rożnych krajach.

Sukces każdej koncepcji $w$ dużej mierze opiera się na badaniach i rozwoju, chociaż sq już znane autobusy amfibie, pojazdy tego typu maja jeszcze przed soba dtuga droge innowacyjnego rozwoju.

\section{WSTĘP}

W ostatnich latach ,pływające autobusy", tzw. "amfibie" lub "wodne autobusy" (amfibus, waterbus) stały się dość rozpowszechnione na świecie.

Większość z nich służy do transportu turystów. Trasa łączy w sobie przejażdżkę po ulicach miasta, a następnie wodną podróż „statkiem”.

„Pływające autobusy” posiadają niezaprzeczalne zalety, pozwalając turystom, nie opuszczając autobusu, zwiedzać.

Ponadto drogi stają się coraz bardziej ruchliwe, dlatego też poszukuje się alternatywnych rozwiązań, które poprawiłyby i przyspieszyłyby transport pasażerski [1].

Amfibie, których wynalazek zawdzięczmy znanemu neapolitańskiemu księciowi Raimondo di Sangro z Sansevero (ok. 1750) lub sir Samuela Benthama (1781). Pierwszy znany samobieżny pojazd typu amfibia, napędzany był para, pogłębiony pojazd kołowy 0 nazwie Orukter Amphibolos, został wymyślony i skonstruowany przez amerykańskiego wynalazcę Olivera Evansa w 1805 roku, aby skutecznie podróżować lądem lub wodą napędzany był dodatkowym źródłem zasilania [2].

\section{AMPHICOACH GTS-1}

To pierwszy na świecie pasażerski autobus-amfibia. Po latach projektowania i udoskonalania konstrukcji, której nie ujawniono. W 2006 roku powstał jego pierwszy prototyp, którego przetestowano na Malcie. „Pływający autobus” zbudowany jest na podwoziu włoskiego Irisbusa. Do napędu posłużyły jednostka wysokoprężna o mocy 250 lub 300 KM połączone z napędem na jedną lub obie osie. W wodzie pojazd napędzany jest silnikiem strugowodnym, dzięki temu, że tylne koła chowają się w podwoziu obniżając opór wody. Wysoko położony środek ciężkości może uniemożliwiać poruszanie po wodzie, gdy wiatr wieje zbyt mocno. Płaska konstrukcja nad podwoziem zapobiega przewróceniu się na wodzie. Front pojazdu jest mocno ścięty, korpus wykonany jest głównie z kompozytu aluminium o grubości $6 \mathrm{~mm}$. Dodatkowe wyposażenie obejmuje: pirotechniczne pasy bezpieczeństwa i automatyczne wyłącenie silnika w przypadku pożaru.
Cena pojazdu na rynku brytyjskim wynosi 280 tys. funtów, w przeliczeniu na walutę polską to ok. 1,4 mln złotych [3].

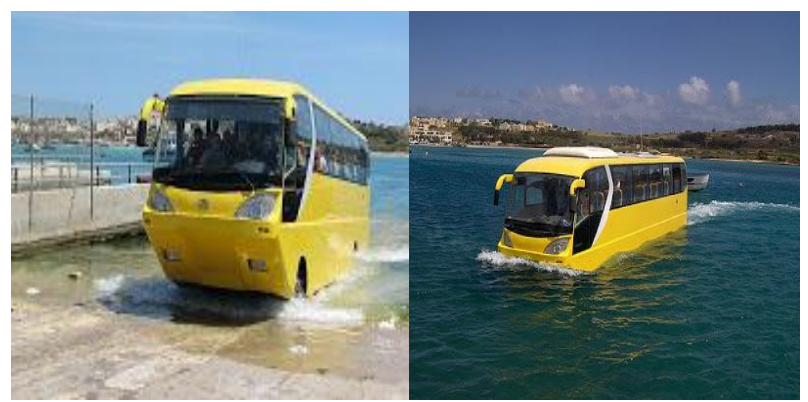

Rys. 1 Widok AmphiCoach GTS-1 [4]

\section{HAFENCITY RIVERBUS}

Pierwszy niemiecki ,pływający autobus” wyposażony jest w klimatyzację, ogrzewanie, system GPS. Pojazd napędzany jest na lądzie przez silnik MAN o mocy $290 \mathrm{KM}$. Napęd wodny jest dostarczany przez dwa silniki wysokoprężnymi Steyr Marine o mocy 156 KM. Ze względu na konstrukcję ,,pływającego autobusu” nie ma toalety na pokładzie. Koszt zakupu to ok. $1 \mathrm{mln}$ euro [5].

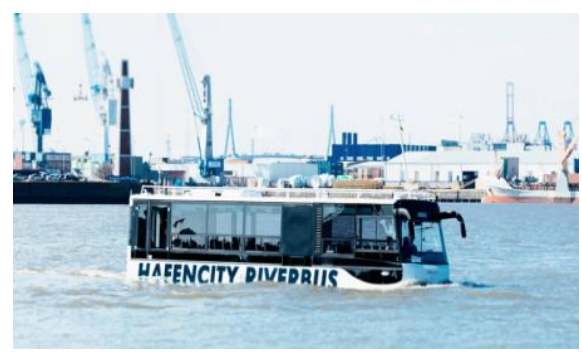

Rys. 2 Widok HafenCity RiverBus [6]

\section{SPLASHTOURS}

Historia tego pojazdu zaczyna się w Rooterdamie, gdzie był testowany przez firmę Splashtours. Producentem niezwykłego pojazdu z Amsterdamu jest holenderska firma Amphibious Transport Vehicles BV z Nijmegen. „Pływający autobus” wykonany jest w oparciu o dwuosiowe podwozie Volvo. Silnik wysokoprężny spełnia normy środowiskowe (niska emisyjność). Posiada uszczelniony, aluminiowy korpus i dodatkowo zawieszenie pneumatyczne. Porusza się po wodzie z prędkością do $15 \mathrm{~km} / \mathrm{h}$.

Dodatkowe wyposażenie to panoramiczny dach oraz 5 wyjść awaryjnych. 


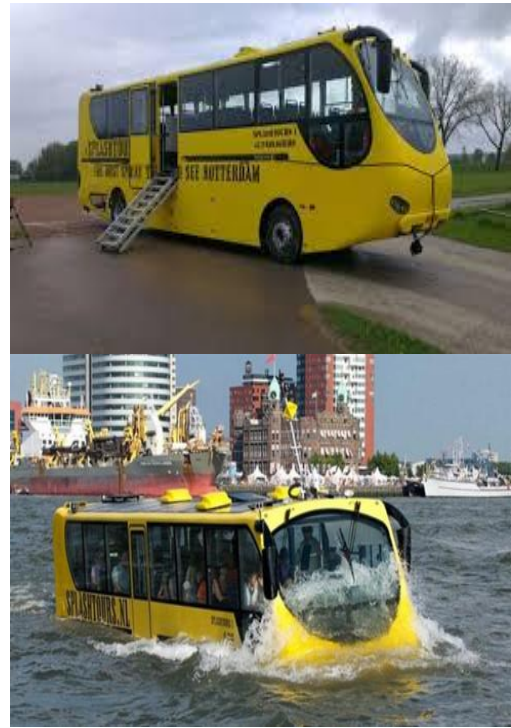

Rys. 4 Widok Splashtours [7]

Koszt autobusowej amfibii przedstawionej na rysunku 4 to 700.000 funtów , czyli czyli ok 3 mln PLN

\section{LADY DUCK}

W 2001 roku został skonstruowany pojazd typu amfibia pod nazwą ,Lady Duck” umożliwia on przewóz osób po drodze i na rzece Ottawie w regionie Kanady.

Pojazd skonstruowany jest na zmodyfikowanej wersji podwozia ciężarówki Forda F-350.

Wyposażony jest w cztery zanurzone i napędzane elektrycznie pompy. Dwie pompy maja wydajność nominalną 39,4 L / min, każda znajduje się w studzienkach spustowych rozciagających się poniżej dna kadłuba w centralnym położeniu pojazdu. Dwie pompy tego samego typu o wydajności 47,4 I / min i 78,8 I / min umiejscowiono w kadłubie przed studniami zęzowymi na ok. 4 m w części przedniej pojazdu. Wyposażenie dodatkowe pojazdu obejmuje: radio VHF, telefon komórkowy i rejestrator głębokości [8].

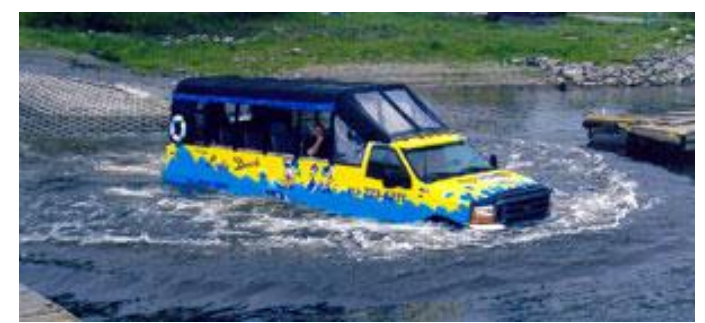

Rys. 5. Widok „Lady duck” na Ottawie

\section{HYDRA TERRA}

W Stanach Zjednoczonych stworzono koncepcję autobusowej amfibii „Hydra Terra”. Pojazd posiada wysokoprężny silnik, który napędza wszystkie koła. Silnik umieszczony jest w centralnej części podwozia pojazdu, aby zapewnić mu równowagę na wodzie. Napęd wodny zasilany jest przez 2 silniki (o niskiej emisji spalin) okrętowe Caterpillar napędzające śmigła z dwoma śrubami. Kadłub ma kształt litery $\mathrm{V}$, wypełniony jest pianką o specjalnych właściwościach wodoodpornych. Pojazd posiada elektroniczny układ kierownicy oraz automatyczną skrzynią biegów. Ponadto ma funkcje zwijania i podgrzewania szyb, aby pasażerowie mogli komfortowo podróżować w każdą pogodę. Amfibia autobusowa zaopatrzona jest w dwa zbiorniki: paliwa o pojemności ok. 227 litrów oraz zbiornik na wodę o pojemności ok. 113 litrów. Dodatkowo ,,pływający autobus" wyposażony jest w Wi-Fi, cyfrowy system dźwięku MP3 i oświetlenie LED, podwodny aparat i przymocowane do niego duże wodoodporne telewizory LCD, dzięki czemu można oglądać podwodny świat. Amfibia może pracować także w niekorzystnych warunkach atmosferycznych (silny wiatr, deszcz i powódź). Dodatkowy sprzęt na pokładzie do użytku w sytuacjach kryzysowych to: 50 kamizelek ratunkowych umieszczonych pod każdym siedzeniem, $1 \mathrm{x}$ pierścienie ratunkowe, $6 \mathrm{x}$ ręcznych race, $3 \mathrm{x}$ spadochronowe race, 2 x pomarańczowe sygnały dymu, $1 \times$ wodoodporne latarki, apteczka pierwszej pomocy. Koszt zakupu pojazdu szacowany jest na $\$ 380000$ [10].

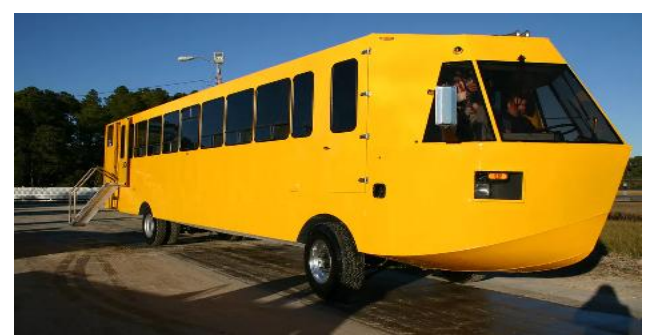

Rys.7. Widok ,, Hydra Terra” [11]

\section{MERCEDES SPRINTER 313 CDI}

W 2017r. Czechach skonstruowano autobus amfibie zmodernizowaną z wersji Mercedesa Sprintera pod nazwę ,,Enjoy Sprinter".

Firma Enjoy Tech Limited zaprojektowała ten pojazd bazując na konstrukcji Mercedesa Sprintera 313 CDI.

„Pływający autobus" posiada zmodyfikowane nadwozie, majace m.in. kilkuwarstwowy korpus z wodoodpornego tworzywa, obudowę kompletnego układu wydechowego oraz klimatyzator ukryty nad miejscem pracy kierowcy. Dodatkowe wyposażenie pojazdu to: wydajna pompa odpowiedzialna za usunięcie wody w kryzysowej sytuacji zagrożenia.

Innowacyjne rozwiązanie to również awaryjny system pompowania w razie wypadku na wodzie oraz oddzielny zbiornik, czyli ochrona przegubów i wału napędowego. Dodatkowo pojazd posiada czujnik rozpoznawczy, kiedy Mercedes Sprinter 313 CDI porusza się po wodzie, czujnik załącza pojazd w tryb żeglarski, utrzymując tylko właściwy kierunek regulowany przy pomocy joysticka. Cena pojazdu prototypowego z wyposażeniem zaczyna się od 9000000 CZK [12].

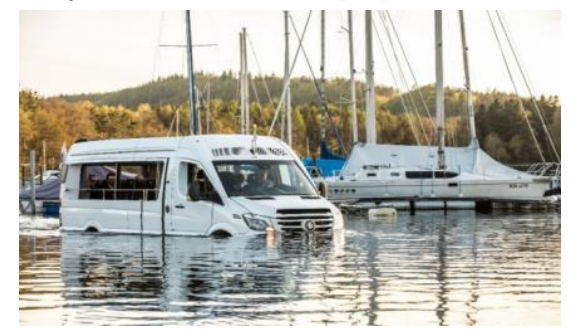

Rys.7. Widok Mercedes Sprinter 313 CDI [13]

\section{AUTOBUSY 9/2018}




\section{SALZBURG HIGHLIGHTS}

W 2016r. miasto Salzburg w Austrii wzbogaciło się o najmniejszy na świecie autobus amfibia. „Pływajacy autobus” posiada 3 silniki o łącznej mocy $630 \mathrm{KM}$. Pojazd wykonany jest z tworzywa sztucznego wzmocnionego włóknami węglowymi.

Model amfibii autobusowej jest produktem na zamówienie, wykonanym w Bawarii, nie przewidziano seryjnej produkcji. Koszt zakupu pojazdu to 700000 euro.

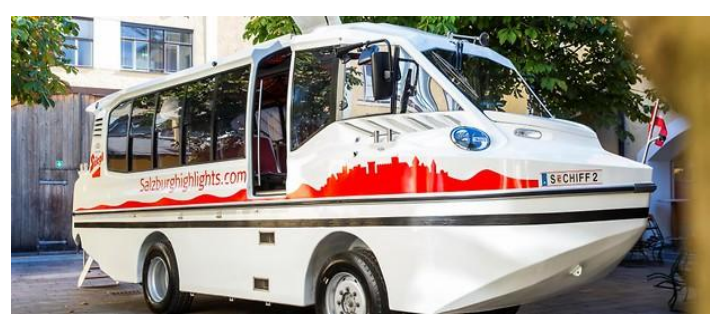

Rys. 8. Widok Salzburghighlights [14]

W tabeli 1 przedstawiono charakterystyczne parametry techniczne wybranych ,pływających autobusów” w różnych krajach. Prezentowane autobusy różnią się od siebie głównie konstrukcja układu zasilania, wymiarami, masą oraz liczbą przewożonych pasażerów. Masa własna ,pływających autobusów” wpływa na ograniczenie liczby przewożonych pasażerów. Warto zauważyć, że amfibia Salzburghighlig spośród porównywanych pojazdów jest najlżejsza i posiada najwyższą wartość prędkości poruszania się po wodzie wynosząca 14 węzłów. Biorąc pod uwagę prędkość poruszania się po drodze, największą wartości osiąga ,,pływający autobus” Splashtours (97 km/h).

\section{PODSUMOWANIE}

„Pływające autobusy” są nowością na rynku, aczkolwiek konstrukcja pojazdu typu amfibia ma już ponad 40 lat historii. Na początku ubiegłego wieku powstawały już pływające samochody, czołgi.

Konstrukcje ,pływających autobusów" znane są już m.in. w Hamburgu, Kanadzie, Czechach, Amsterdamie, USA. Przedstawione w artykule konstrukcje amfibii autobusowych różnią się od siebie układem zasilania, prędkością poruszania na lądzie i na wodzie, możliwościa zanurzenia, wymiarami konstrukcji oraz możliwą liczbą przewożonych pasażerów.

Podróżowanie autobusowa amfibią ma stanowić unikalne doświadczenie łączące dwie perspektywy - przejażdżkę po ulicach miasta i przeprawę wodną. Wykorzystanie amfibii jest jednym z rozwiązań, które umożliwia budowanie alternatywnych tras w celu wyeliminowania korków.
Tabela 1. Dane techniczne porównywanych autobusowych amfibii

\begin{tabular}{|c|c|c|c|c|c|c|c|}
\hline & $\begin{array}{l}\text { AmphiCoach } \\
\text { GTS-1 }\end{array}$ & $\begin{array}{l}\text { HafenCity } \\
\text { RiverBus }\end{array}$ & Splashtours & $\begin{array}{l}\text { "Lady } \\
\text { Duck" }\end{array}$ & Hydra Terra & $\begin{array}{c}\text { Mercedes } \\
\text { Sprinter } \\
313\end{array}$ & $\begin{array}{c}\text { Salzburg } \\
\text { Highlights }\end{array}$ \\
\hline Masa $[t]$ & 15 & - & 21 & 13 & 17 & - & 7,7 \\
\hline Długość [m] & 12 & 12,07 & 14,2 & 8,46 & 39 & 7,2 & 9,9 \\
\hline Wysokość[m] & - & 3,75 & 3,22 & 3,5 & 6,6 & - & 3,45 \\
\hline $\begin{array}{c}\text { Szerokość } \\
{[m]}\end{array}$ & 2,5 & 2,54 & 2,55 & 2,49 & 2,5 & 2,36 & 2,4 \\
\hline $\begin{array}{l}\text { Maksymalna } \\
\text { prędkość na } \\
\text { lądzie [km/h] }\end{array}$ & 65 & 65 & 97 & 45 & 75 & 90 & - \\
\hline $\begin{array}{l}\text { Maksymalna } \\
\text { prędkość na } \\
\text { wodzie } \\
\text { [węzlów] }\end{array}$ & 8 & 7 & 8 & 4 & 7 & 8,4 & 14 \\
\hline $\begin{array}{c}\text { Zanurzenie } \\
{[\mathrm{cm}]}\end{array}$ & - & - & 1,8 & 0,84 & 4 & 85 & 85 \\
\hline $\begin{array}{l}\text { Zasilanie } \\
\text { 1)na lądzie } \\
\text { 2)na wodzie }\end{array}$ & $\begin{array}{c}1 / 2 \\
\text { wysokopreżne } \\
\text { silikiki } \\
\text { polaczone z } \\
\text { napędem na } \\
\text { jedną lub obie } \\
\text { osie, } \\
\text { 2) silnik } \\
\text { strugowodny }\end{array}$ & $\begin{array}{l}\text { 1)silnik MAN o } \\
\text { mocy } 290 \mathrm{KM} \text {, } \\
\text { 2)dwa sinniki } \\
\text { wysokopreżnymi } \\
\text { Steyr Marine o } \\
\text { mocy } 156 \mathrm{KM} \text {. }\end{array}$ & $\begin{array}{l}\text { 1) glównyy silnik: } \\
\text { Volvo; } \\
\text { dodatkowe } \\
\text { zasilanie } \\
\text { elektryczne:190 } \\
\text { baterii litowo- } \\
\text { jonowych, } \\
\text { 2)stery } \\
\text { strumieniowe o } \\
\text { 10kW i } 7.5 \mathrm{~kW}\end{array}$ & $\begin{array}{c}\text { 1)silnik } \\
\text { benzynowy, } \\
\text { 2)zewnętrzny } \\
\text { Mercruise, } \\
4 \text { pompy } \\
\text { elektryczne }\end{array}$ & $\begin{array}{l}\text { 1) jeden } \\
\text { Caterpillar C7 } \\
210 \mathrm{KM} \text {, } \\
\text { 2) dwa } 300 \\
\text { KM silniki } \\
\text { wysokoprężne } \\
\text { Caterpillar C7 } \\
325 \mathrm{hp}\end{array}$ & $\begin{array}{l}\text { 1)129- } \\
\text { konny } \\
\text { turbodiesl } \\
\text { opoj. 2,11 } \\
\text { 2)morski } \\
\text { silnik JET } \\
\text { o mocy } \\
40 \mathrm{~kW} \text {. }\end{array}$ & $\begin{array}{l}\text { 1)sininik o } \\
\text { mocy } 180 \\
\text { KM, } \\
\text { 2)2siliniki } \\
\text { wodne: } \\
\text { Volvo } \\
\text { Penta o } \\
\text { mocy 225 } \\
\text { KM }\end{array}$ \\
\hline $\begin{array}{l}\text { Liczba miejsc } \\
\text { dla } \\
\text { pasażerów }\end{array}$ & 50 & 40 & 50 & 11 & 50 & 12 & 26 \\
\hline
\end{tabular}

źródło: opracowanie własne

\section{BIBLIOGRAFIA}

1. https://wilcomanufacturing.com/the-history-of-amphibiousvehicles/

2. Gawande M., Mali P., Amphibious Vehicle, International Research Journal of Engineering and Technology (IRJET),2016,s.137-138

3. http://www.thepetrolstop.com/2010/08/amphicoach-gts-1.html

4. http://www.v10.pl/AmphiCoach,GTS1,czyli,plywajacy,autobus,2 9453.html

5. http://www.maritimejournal.com/news101/vessel-build-andmaintenance/ship-and-boatbuilding/riverbus-service-forhamburg

6. https://www.vesseltracker.com/en/Ships/Hafencity-RiverbusI1865817.html

7. http://www.infobus.pl/autobusowa-amfibia-wamsterdamie_more_53608.html

8. http://www.bst-tsb.gc.ca/eng/rapportsreports/marine/2001/m01c0033/m01c0033.pdf

9. http://www.camillc.com/hydraterra.htm

10. http://www.marinelandtours.com/hydra_terra_amphibious.php

11. http://infobus.pl/sprinter-jako-autobusowa-amfibia-z-czechmore_95630.html

12. https://40ton.net/czeska-amfibia-czyli-mercedes-sprinter-313cdi-ktory-moze-zanurzyc-sie-nawet-85-centymetrow/

13. http://www.krone.at/528882 
Swimming buses

The article presents innovative concepts of the construction of ,,swimming buses" as a means of transport, both on land and on water. Amphibian is a dual-use vehicle. It can be used for various applications in the military area, rescue operations, as well as tourism. The article focuses on the description of the concept of an ,swimming buses" in various countries. The success of each concept is largely based on research and development, although amphibious buses are already known, and vehicles of this type still have a long way to go through innovative development.

Key words: water bus, land bus, amphibious bus 